\title{
How to Carry out Teaching Evaluation in Music Education in Regular Institutions of Higher Learning
}

\author{
Yi Ji \\ School of Music and Dance \\ Qujing Normal University, \\ Qujing, Yunnan, China 655011
}

\begin{abstract}
Nowadays, the teaching quality of teachers is mainly measured by teaching quality evaluation. Therefore, teachers' teaching quality evaluation has become priority among priorities in teaching management of colleges. This article mainly discusses relevant contents of teaching evaluation in colleges from department of music in colleges, to more clearly grasp teaching evaluation system of music major in colleges of our country, better optimize teachers' professional level and better serve teaching.
\end{abstract}

Keywords-teaching evaluation; music education; evaluation principle; evaluation scope; evaluation criterion

\section{INTRODUCTION}

Nowadays, in many colleges of our country, teaching evaluation gradually becomes the mainstream. Its function embodiment is more and more important. The education of music major is the same. But four problems that "why to evaluate", "who is going to evaluate", "how to evaluate" and "how to guarantee evaluation quality" only center on music education in colleges. It leads to the fact that teaching evaluation is still imperfect in music education of colleges.

\section{DEFINITION OF TEACHING EVALUATION}

Before discussing music teaching evaluation in regular institutions of higher learning, it is necessary to know what teaching evaluation is. Teaching evaluation in colleges refers to the process to "base on teaching objectives, set scientific standard, use all effective technological means of evaluation, measure, analyze and compare process and result of teaching activities and make value judgment." This definition shows that teaching evaluation can serve as standard to measure teaching quality. Therefore, in music education in colleges, teaching evaluation can play the good role of supervision and guidance, urge teachers in colleges to enhance the teaching quality and improve teaching methods.

\section{TEACHING PoINTS OF Music EdUCATION}

Different from education of other subjects in colleges, music education pays more attention to expertise and guidance of college teachers and practicality of classrooms. In the past music teaching in colleges, teaching evaluation mainly aims at teachers' teaching level. The state that students grasp the knowledge taught by teachers is in the second place. But with the requirements of new curriculum reform, now teaching evaluation in colleges mainly follow the educational thought that centers on aesthetic appreciation and takes students as the principal part. Therefore, under this background, teaching evaluation of college teachers shall consider the following factors.

- Teaching evaluation in colleges shall pay attention to recording true reflection of teaching process. What does the teacher say in the interaction with students? What do they do? How many times do they do this thing? How long do these teachers spend in different teaching links? Teaching evaluation in colleges shall collect more facts in teaching, in order to provide basis for objective evaluation.

- Teaching evaluation in colleges shall pay attention to students' participation state in class, association and communication, direction of thinking and whether students reach learning objectives. In students' participation state, it is necessary to observe students' emotion in class and whether they can actively coordinate with teachers to carry out the teaching in class. Students' association and communication refer to that in teaching process, whether students actively respond to teachers' questioning and reaction and whether the communication and cooperation between students are friendly. Students' direction of thinking refers to that whether students have their unique understanding and insight in teachers' teaching process, whether they can carry out free creation full of imagination and independent study on existing cognitive basis and solve problems independently. The state that students achieve learning objectives refers to that whether students can learn consciously in teachers' teaching process and grasp the contents taught by teachers.

- Teaching evaluation in colleges shall pay attention to whether teachers can turn professional knowledge, cultural knowledge and moral character mastered by themselves into ways that can be accepted by students, and use the infection of music to influence students. Teachers have substantial differences from scholars. It demands teachers to have high degree in mastering knowledge, exert their abilities and behaviors to 
influence students and become models for students to learn and imitate.

- Teaching evaluation in colleges shall pay attention to that whether teachers can extend knowledge taught in class to outside class for students to learn and understand. After teaching a lesson, a good teacher in colleges can let students perceive many things and benefit them for lifetime, directly influence the form of students' thinking model and value and have effects on students' emotion and their thinking on the world.

\section{Problems and Reasons of Music Teaching EVALUATION IN COLLEGES}

\section{A. Main Problems and Its Harms on Teaching Evaluation in Regular Institutions of Higher Learning}

1) Music teaching evaluation in colleges has ambiguous objectives and single standard: In teaching evaluation of colleges, we shall know that the objective of teaching evaluation is to direct teaching quality. It is a value judgment on whether teachers' teaching quality reaches the standard. The ultimate purpose of teaching evaluation is also to promote educational value and improve overall quality and efficiency of education. However, in music teaching evaluation of colleges, many colleges cannot truly realize the essence of teaching evaluation. On the contrary, they take teaching evaluation as task issued by higher authorities. They only complete it as a task. Furthermore, many teachers in colleges take teaching evaluation as the tool to compare with the higher. They try every means to achieve a good result of teaching evaluation, use the result of teaching evaluation to show off, which let the teaching evaluation become utilitarian.

Besides, music teaching in colleges has different characteristics because of different levels. But the content standard of teaching evaluation is the same. It has the same requirement for music teaching evaluation in colleges at all levels without considering individuality of different colleges.

2) The phenomenon that college teachers muddle through their work springs up in music teaching evaluation: For schools, through music teaching evaluation, they can know the situation of teaching, master education level of music and quality condition and find deficiencies in running a school, formulate corresponding rectification measures, clearly know the direction that they shall make efforts. However, teaching evaluation is "distorted" in implementation. Music teachers in colleges regard teaching evaluation as the process that the school inspect and test their work. They are afraid that the result of teaching evaluation is not ideal, which influence their development and rating and the allocation of funding for research topics. So it appears the phenomenon that many music teachers in colleges muddle through the teaching evaluation.

\section{HOW TO CARRY OUT TEACHING EVALUATION IN MUSiC EDUCATION OF COLLEGES}

\section{A. Define Concept of Music Teaching Evaluation in Colleges}

Music teachers in colleges shall understand the necessity to carry out teaching evaluation. With the development of culture college teachers have increasingly deep understanding on teaching. They accept teaching evaluation gradually. Music teachers in colleges shall seek their footholds under three different value systems, namely improve teaching quality, promote professional development and serve scientific management and reasonably seize the balance point between the three value systems. Therefore, in practice process, music teachers in colleges will appear the situation of value conflicts.

1) Pay attention to cultivation of quality of music teachers in colleges: Generally speaking, the teaching evaluation for work of music teachers in colleges will use the efficiency of their work as the reference standard. The ultimate purpose of music teaching in colleges is to cultivate high quality talents and promote comprehensive development of students. The starting point to cultivate high quality talents is that music teachers in colleges shall skillfully master professional knowledge; furthermore, they shall thoroughly pass knowledge mastered by them to students.

2) Pay attention to professional development of music teachers in colleges: The first factor to influence music education is music teachers. The higher the professional quality of music teachers, the higher the comprehensive quality of students will be. Therefore, in order to ensure the high quality of talents in colleges, music teachers in colleges shall pay more attention to requirements of self-development. However, in colleges of our country, we always neglect the requirements of college teachers for sense of honor, selfaffirmation and self-actualization, so that the value of existing teaching evaluation cannot be embodied. Meanwhile, more and more people realize that the professional growth of college teachers can only rely on teachers' self-reflection and promotion. So in order to improve the quality of music teaching evaluation of colleges, it is necessary to think by standing on the position of music teachers, promote the development of music teachers, truly pay attention to music teaching and improve the quality of music teaching.

3) Music teachers in colleges shall serve management decisions of colleges: With continuous optimization of internal management system in colleges, it becomes a big problem of colleges about how to establish reasonable, efficient and vital educational management system. In teaching management, the teaching evaluation of teachers is an important content. Through analytical judgment on the situation of teachers' teaching, it can check whether teaching plans of administrative staff in schools are reasonable and whether it is very important to help to complete teaching objectives on feasibility. However it cannot be ignored that traditional single teaching evaluation has very big subjectivity and contingency and seriously influences the level of teaching management in colleges. Therefore, music teaching evaluation in colleges shall take relevant influence factors into full consideration to formulate reasonable teaching quality management system of schools. 
Although there are slight differences in embodiment of music teaching evaluation in colleges, the ultimate purpose is teaching activities and to follow objective law of teaching. In colleges, the music teaching management system is only an auxiliary means. It shall not play a decisive role, but devote to creating a learning model full of enthusiasm and innovation between teachers and students.

\section{B. Pay Attention to Principal Part of Music Teaching Evaluation in Colleges}

1) The principal part of music teaching evaluation in colleges is students: Students are receivers and eyewitnesses in teaching process of music teachers in colleges. They have direct and profound experience and feelings for teachers' teaching model. It is the logic basis of music teaching evaluation in colleges. Besides, the mind of college students in colleges has tended to be fully mature. They have relatively correct cognition and judgment. As the main participants of teaching evaluation, students have the truest and most valuable teaching evaluation on teachers. Furthermore, the results of music teaching evaluation in colleges can be served as the reference basis for students to choose courses. It can also stimulate music teachers in colleges to pay more attention to students' experience feeling and take the requirements of students as the main teaching factors.

The main purpose of students' teaching evaluation is to make music teachers in colleges find problems in teaching and correct them to optimize teaching activities. In order to improve the existing teaching evaluation in colleges, it is necessary to establish a unique teaching assessment model. In other words, before starting the course, students and teachers jointly come to an agreement about teaching objectives and teaching results that they want to achieve as well as the knowledge level that students shall reach, and formulate corresponding teaching evaluation system; after completing the course, students make teaching evaluation on music teachers in colleges according to teaching evaluation system formulated initially. This kind of teaching assessment model unifies objectives between students and teachers, fully mobilizes active initiative and enthusiasm of teachers and students. It can also promote communication and understand requirements of each other.

2) The foundation of music teaching evaluation in colleges is self-evaluation of teachers: Teaching work of music teachers in colleges is very complicated. They put huge energy in each class. The particularity of the post of music teacher in colleges demands they must give full play to their potential and finally achieve self-value. In addition, music teachers in colleges reflect their work in teaching process, which can form a spontaneous teaching motive. Researches show that the spontaneous power of teachers is more long-lasting than dynamic factor of external stimulus. So music teachers in colleges can carry out self-evaluation through teaching evaluation, and then enhance the power of teaching. It can timely adjust deficiencies in teaching process, better urge music teachers in colleges to make deep teaching research and continuously improve their teaching ability.

\section{Improve Method System of Teaching Evaluation on Music Teachers in Colleges}

In different scopes, the effects that music teaching evaluation in colleges has are different. Now colleges formulate mark sheet and teaching evaluation system as the standard for students to mark teachers and evaluate the teaching quality of music teachers in colleges, but there are many unstable factors. Therefore, it is necessary to evaluate teachers' teaching quality from multiple dimensions, pay attention to qualitative evaluation to make students' evaluation on teachers more reasonable.

At present, many problems exist in music teaching evaluation in colleges, such as attach less importance to the process but pay attention to the result, and pay attention to teachers' teaching activity and ignore students' acceptability. Therefore, music teaching evaluation in colleges shall improve method system of teaching evaluation.

\section{Improve Management Mechanism of Music Teaching Evaluation in Colleges}

At present, the teaching evaluation management system for teachers in colleges of our country is mainly provided for administrative staff in colleges to supervise and manage teaching process. They ignore the subject consciousness of teachers as professional personnel, which influence the results of music teaching evaluation in colleges. In view of this, put forward the following strategies.

1) Music institutes and departments in colleges shall set special teaching evaluation organizations: The existing teaching evaluation organizations in colleges integrate with other functional departments. A lot of work is restricted by other departments. It always seems that the implementation strength is inadequate. Therefore, they can establish teaching evaluation organizations of resistance in music institutes and departments in colleges to let them operate according to requirements. When choosing administrative staff, it is necessary to pay attention to whether they master professional knowledge and theory and whether they have rich teaching experience and judgment. Therefore, professional teaching evaluation organizations can independently take charge of music teaching objectives and teaching management in colleges, formulate detailed assessment schemes, in order to guarantee that teaching evaluation can improve the quality of talent cultivation in colleges and urge music teachers in colleges to develop their professional knowledge.

2) Music institutes and departments in colleges shall make incentive system such as performance evaluation sound: The teaching quality of teachers in colleges can be embodied through teaching evaluation. Therefore, it is essential to integrate performance evaluation in teaching evaluation. Besides, colleges in our country have a long history in implementing teaching evaluation. Although it has much superiority, there are many deficiencies. For example, music teachers in colleges have not high initiative to carry out selfcriticism and self-reflection. Under overall situation of our country, it is necessary to integrate incentive methods such as promotion and rewards in teaching evaluation, properly combine teaching evaluation of performance rewards and 
punishment, and give full play to positive incentive factors in evaluation, make music teachers in colleges can have the will to make self-reflection and improve.

3) Music institutes and departments in colleges shall improve information feedback system: Teaching evaluation in colleges can prompt the teaching progress. But strictly speaking, only by effectively putting the results of teaching evaluation into teaching work can maximize the function of teaching evaluation. The timely feedback of music teaching evaluation results can let music teachers in colleges find problems that they produce in teaching process, formulate corresponding rectification measures, improve in time, and then enhance the teaching quality.

Music teaching evaluation in colleges of our country always keeps the management orientation and implements through integrating results of teaching evaluation with management decision, and ignores the effects of teaching evaluation on promoting teachers' teaching, which lead to the fact that the feedback of music teaching evaluation results in colleges isn't timely. We can improve through the following points: Firstly, the feedback of music teaching evaluation results in colleges shall pay attention to quantity and quality and have certain quantity and quality; secondly, give affirmation to teachers who have good teaching evaluation, promote good methods sorted out by them to increase sense of accomplishment, remind and help teachers who have poor teaching evaluation, discuss with them together and put forward opinions and methods to improve; finally, pay attention to ways of feedback of teaching evaluation results, grasp psychology of college teachers. It is forbidden to randomly open evaluation results and rankings.

\section{CONCLUSION}

The implementation of music teaching evaluation in regular institutions of higher learning can promote efficient and scientific development of music teaching in colleges and has great help for music teachers in colleges to realize teaching objectives and teaching contents. Besides, the music teaching evaluation in colleges also guides the development and reform of teaching, stimulates enthusiasms of students and teachers, improves teaching efficiency, corrects teaching attitudes of teachers in colleges and improves teaching quality, in order to cultivate more comprehensive talents.

\section{REFERENCES}

[1] Written by Fink, Create Meaningful Learning Experience: Design Principles of Comprehensive University Course [M], translated by Liu Ying, Hangzhou: Zhejiang University Press, 2006.

[2] Qian Cunyang. Several Considerations on Improving Classroom Teaching Quality Evaluation of Colleges [J], Higher Education of Sciences, 2006.(2).25-27.

[3] Ma Da. Music Education of Chinese Schools in 20th Century [M], Shanghai: Shanghai Educational Publishing House, 2002.5. 